\title{
The Quagmire of Noise Pollution and Other Interferences with the Enjoyment of Land among Nigerians
}

\author{
Titus Kehinde Adekunle1, Mary-Anne Ajayi² \\ ${ }^{1}$ Institute of African Studies, University of Ibadan, Ibadan, Nigeria \\ ${ }^{2}$ Faculty of Law, Bowen University, Iwo, Nigeria \\ Email: ktadekunle@gmail.com
}

How to cite this paper: Adekunle, T. K., \& Ajayi, M.-A. (2018). The Quagmire of Noise Pollution and Other Interferences with the Enjoyment of Land among Nigerians. Beijing Law Review, 9, 697-708. https://doi.org/10.4236/blr.2018.95038

Received: September 29, 2018

Accepted: November 27, 2018

Published: November 30, 2018

Copyright (c) 2018 by authors and Scientific Research Publishing Inc. This work is licensed under the Creative Commons Attribution International License (CC BY 4.0).

http://creativecommons.org/licenses/by/4.0/

\section{(c) (i) Open Access}

\begin{abstract}
Land is a great asset to humanity but the effort of man to derive the maximum benefit from land is often fettered by the right of his neighbour to utilise the adjacent landed property in line with his own pleasure. The interference manifests in terms of noise pollution, discomfort and other disturbances that affect the enjoyment of the land owned by other landlords. Are the disturbances and interference justified or justifiable in the face of serious health hazard which they posed to other land users? Could anything be done to put a stop to those excesses of man or man's callousness to fellow man? This paper is set to investigate these and other similar questions, and as well, interrogate the socio-cultural dynamics that affect and prevent the enjoyment of land to the fullest in the country.
\end{abstract}

\section{Keywords}

Land, Noise Pollution, Disturbances, Enjoyment of Land, Health Hazard

\section{Introduction}

Various activities which man carries out on land from day to day have rendered him helpless in surviving without having recourse to this natural gift to humanity for his existence. The importance of land to man cannot, therefore, be overstretched. Starting from the very basic need of man for a quiet place to rest his head at the end of each day's job to the requirement of performing his activities in a serene environment, land actually plays an important and dominant role in the affairs of man. Man, therefore, walks around on land, works on it and carries out his expansionist tendencies on this natural endowment in his bid to be a 
landlord both in the low and high brow areas of the different cities that spread all over the globe. Land, indeed, is an asset to man and as Albert et al. (1995: p.

16) observe, landed property is a key investment, an asset and a status symbol in many towns and cities around the world.

Now, the continuous enjoyment of this vital asset by man is being threatened, disturbed or invaded by the many uses to which he puts it from time to time. This deprivation of his right is however being unleashed on him given the freedom he enjoys in making use of his property. For, according to Section 43 of the Constitution of Nigeria, 1999 which is still an extant law in the country, an average Nigerian is entitled to put up an immovable property anywhere in the country. The section provides:

Subject to the provision of this Constitution, every citizen of Nigeria shall have the right to acquire and own immovable property anywhere in Nigeria.

This is however subject to the right of the Government to acquire the property for any overriding public interest if and when the need arises, in accordance with Section 44 (1) of the Nigerian Constitution. Also, the Government's right over the entire property and control of all minerals, mineral oils and natural gas overrides any personal right to property, in line with Section 44 (3) of the Nigerian Constitution. That simply means that all landed properties that contain mineral resources are deemed to belong to the Federal Government of Nigeria. Such landed property, when acquired, must be adequately compensated for and the owner must be given access to the property for the determination of his interest and the amount of compensation payable to him. But the right of the citizen to own property is being curtailed, albeit illegally, by fellow citizens who, in the process of making use of their own property have inflicted series of inconveniences, discomforts and even injuries to the owner and his property.

\section{Nature of Interference with the Land of Others and Hazards of Noise Pollution}

Interference with other people's land can be deliberate or accidental depending on the motive of the intruder, but whichever one it is, the impact it will make on another man's property could be damaging, destructive and ruinous. Construction of water runways, sewage tanks, toilets, allowing water to escape to or on another man's land and other such instances are several ways of interfering with another man's property which could all constitute nuisance and/or disturbance to the owner of adjacent land. There are, however, two types of nuisance, namely, public nuisance and private nuisance. A public nuisance occurs where the conduct or activity of a man causes some inconveniences, disturbances or discomfort to the general members of the public. It is one which inflicts damage, injury or inconvenience to the generality of the population of a class of people within its ambit. It may not necessarily be linked with the user of land (Street, 1976: p. 218). On the other hand, private nuisance protects the individual owner 
of land from substantial interference with the enjoyment of his property (Kodilinye \& Aluko, 2010: p. 95). It interferes with a person's use and enjoyment of land or of some right, such as an easement, connected with land. It is violation of a person's private rights as opposed to a violation of rights which he enjoys. It is the kind of nuisance that may be and is usually caused by a person doing on his own land something which he is lawfully entitled to do. Consequently, it was explained in the case of Thompson Schwab v. Costaki that the conduct of a land owner becomes a nuisance when the consequences of his act are not confined to his own land but extend to the land of his neighbour by (a) causing an encroachment to his neighbour's land, when it invariably becomes a trespass, (b) causing damage to his neighbour's land or building, or (c) unduly interfering with his neighbour in the comfortable and convenient enjoyment of his neighbour's land. In other words, the tort of private nuisance affects the landed property of the individual whereas public nuisance, though caused over the usage of land by members of the public, it may not necessarily be linked to the user of the land. In fact, it has been said that nuisance is an interference with, disturbance or annoyance to a person in the exercise or enjoyment of (a) right belonging to him as a member of the public, when it is a public nuisance, (b) his ownership or occupation of land or of some easement, profit or other right used or enjoyed in connection with land, when it is a private nuisance (Clerk, Brazier, \& Lindsell, 1995: p. 560).

Moreover, most of the inconveniences and discomforts that often resulted from nuisance emanate from private nuisance as human beings are fond of using their private properties to cause the annoyance of others. Then, it must be noted that the distinction between private and public nuisance is of importance at common law in view of the consideration of the proper person who should initiate proceedings. For instance, a private individual can only take proceedings in his own name in respect of an injury sustained from public nuisance, where he has suffered some particular, direct and substantial damage over and above those sustained by the public at large; or when the interference with the public right involves a violation of some private right of his own, threat or damage to his property. He can also exercise such a right if conferred on him by statute. At any rate, the nuisance must have caused some injury (Dymond v. Pearce ${ }^{2}$ ). In all other cases, known as relator actions, proceedings must be brought with the sanction and in the name of the Attorney-General. However, this restriction imposed at common law on the right of action in public nuisance is inconsistent with the provision of section 6 (6) (b) of the Constitution of the Nigeria, 1999 and, to that extent, is void. That section provides:

The judicial powers vested in accordance with the foregoing provisions of this section-(b) Shall extend to all matters between persons, or between government or authority and to any person in Nigeria, and to all actions ${ }^{1}(1956) 1$ W.L.R. 335, 338. ${ }^{2}(1972) 1$ All ER 1142. 
and proceedings relating thereto, for the determination of any question as to the civil rights and obligations of that person.

There is, therefore, no restriction or limitation on the right of any individual in Nigeria to institute an action in nuisance as at today.

Be that as it may, the problem of noise pollution is another serious issue which poses danger to citizens throughout the country. The noise making emanates from loud speakers displayed by churches, mosques, individuals, sellers of cassette and $\mathrm{CD}$ as well as those celebrating events like naming ceremonies, house warming and burial ceremonies of aged people. Other sources of such pollution include gas flaring industries and factories using heavy-duty equipment from which noise, vibration and smoke escape into other people's land.

As for the religious centres, Nigeria seems to have the largest number of churches per capital in the world and a fertile soil for the growth of independent churches (Adesanya, 2011). Religious centres are springing up at an incredible rate, being erected in various places such as abandoned buildings, shops and other available spaces. In fact, Adesanya (2011) observed that worship comes up in warehouses, hotels, abandoned cinema houses, studios and other public places, and it is common sight to see a minimum of fifty different religious centres on a street of four kilometres long. Very common sight in the country, again, is the erection of religious centres in individuals' houses of the Muslims faithful. All this is probably borne out of the understanding that the country is a place where freedom of worship is freely tolerated, but attendant to this culture is the hazard of noise pollution within the environment and its effect on the health and well-being of the citizenry.

\section{Use of Land}

Land encompasses structures such as dwelling houses, factories and places used for offices, schools, shopping malls and other similar locations. Generally, it includes things that are permanently attached to the soil, that is, a range of resources which surpass private property (Njogu \& Dietz, 2006). This implies that land comprises a wide range of resources such that it becomes difficult to keep all land rights in a particular society in the hand of a single person. However, in Africa, different people tend to have different rights on the same land over different land resources (Bruce, 1988; Poteete, 2010) and this has triggered off many disputes over land in some parts of the continent including Nigeria (Azeez \& Onyema, 2013). Moreover, land has many uses for different people as its usefulness is not only economic and social but, even, spiritual. For instance among the Igbo of the Eastern part of Nigeria, the importance attached to land is so great that Uchendu (1965: p. 22) once observed:

Land means many things to the Igbo. It is the domain of the earth-goddess, a burial place for the ancestors, a place to live on and make a living. Land is one of the important assets of the people. It is a source of security which is emotionally protected from alienation. It is believed that a people cannot 
have too much land and that no opportunity to acquire rights in land should be lost. ...that all land is owned; that there is no concept of abandonment of land or no man's land.

Likewise, among the Yoruba of South-western Nigeria, land is commonly used as an object of oath-taking. In cases where there is a dispute over the ownership of a parcel of land, people are often asked to drink a mixture of soil and water to proof or establish the true owner of land. There is that belief that whoever lies as to the ownership of the land is bound to be afflicted with a serious disease and eventually dies. In other word, land is not only an asset but a spirit-possessing object which is feared and revered among the people.

It is this diverse usefulness of land that made the demand for it so competitive to the extent that, according to Keke (2014: pp. 1-6), no land exists without an owner although that ownership may be the basis for dispute. And, the dispute may be due to the use to which the land is being put by the owner. Such use may interfere with the use of the owner of the adjacent land which may later become a veritable source of litigation.

Besides the above facts, land also serves as a link between the supernatural being, the dead and the living (Otite \& Ogionwo, 2001). Equally important is the fact that it is used for building of places of worship such as churches, mosques, groves and shrines where people approach and venerate their God and gods in different ways. Above all, every idea that human beings conceive or think of on earth is executed on land. Hence, a Yoruba adage says: o gbori ile o jepo, ogbo-ri ile o mumi, o gbobri ile o se ibaje, ase d'owo eni to ran e wa saye. Transliterated, this means that if you dwell on land and taste oil; you dwell on land and drink water and you dwell on it and engage in evil, your judgment lies with your creator. That is, if you do any evil on earth, your creator will judge you accordingly.

Moreover, land is used for erection of different structures among Nigerians but it is specifically used as a means of communing with the spiritual world by the Igbo just as the Yoruba adopt land as an object of oath-taking. However, the use of land for erection of places of worship like churches, mosques and shrines is not peculiar to any particular ethnic group as everybody worships and venerates his God or god in his own way standing on and making use of land as a place for such veneration and supplication.

Everybody, however, has the right to use his land for any purpose that pleases him. Whatever a person does with his own landed property is no business of any other person, even of the neighbour living next to him on the land. We are in a free world, simply at liberty to please ourselves with our property or possession! But then, our freedom to make use of our land should not interfere with the use to which another person puts his own land as any such interference would constitute a nuisance or trespass to that other person.

\section{Illegal and Discomforting Noise Pollution over Land}

Noise is a sound of any kind, especially a loud or a disturbing sound (Read et al., 
2013) and when it is polluted, it become shoarse, riotous and unpleasant to the human ear. According to Okorodudu-Fubara (1988), noise consists of sound which is transported by air. When sound echoes into the surrounding, it has a damaging effect on the human ear, health and well-being. In fact, Field (1993) defined noise pollution as unwanted excessive harmonious sound that has undesired physiological and institutional effects on individuals. There is, however, a growing awareness that noise could do a lot of damage to the hearing ability of human being even though people hardly bother about such problem until it comes to a head. According to Sugden (1980), in most instances, the effects of noise occur after relatively long periods of exposure to noise. He further suggested that no individual should be exposed to a noise level as high as 135 decibels ( $\mathrm{dBA}$ ) for any period however short without ear protection and, even with protection, $150 \mathrm{dBA}$ should be the absolute limit. It has been contended that people who live around the big cities where we have heavy industrial equipment installed in different factories are likely to go through the process of gradual or partial deafness as their sensitive ear drums are being bombarded daily by a continuous barrage of environmental noise overflowing from ear-shattering, drum size speakers of mosques and churches (Asuelumien, 1984). Likewise, Dickson et al. (2012) disclose that the sources of religious centres' noise include: the use of ear-shattering loud speakers by Christians and their Muslims counterparts during morning and night worship sessions; and the drum beats of adherent of African Traditional Religion especially in the course of their festivals. Again, during the annual Ramadan festival, Muslims often resort to singing and drum-beating including call-to-prayer messages late in the dead of the night and, through these activities, disturb the sleep and comfort of their neighbours. Similarly, Ayantayo (2005) states that many of these religious centres place at strategic corners of their auditoria, space drum size speakers, most of the time nearer the windows and doors of their neighbours, and thereby disturb their peace and privacy as a result of the noise that comes out from the speakers.

Excessive noisy nature of the environment prevents the neighbours from enjoying their sleep at night or function effectively in their homes. This assertion found corroboration in Vijayalakshmi (2003) who declares that millions of people are exposed to noise pollution with the increasing number of patients with hearing loss, high blood pressure and headaches. Of essence here is the case of Alhaji Oladele v. Pastor S. Ajisafe ${ }^{3}$ in which the Plaintiff instituted an action against the Defendant for nuisance while claiming N500,000 (about \$1370) damages. The Plaintiff claimed he could not sleep at night and suffered hypertension and a damaged eye due to the excessive noise emanating from the drum beats from the Defendant's church. The Defendant responded that noise did ooze out of the speakers mounted on the minaret of the Plaintiff's mosque built within his compound, and that it was that noise that caused the Plaintiff sleepless night. Unfortunately, the case was withdrawn by the Plaintiff after he and

${ }^{3}$ Unreported Ibadan Magistrate Court Suit No. MRN/8/2015. 
his witnesses had given evidence. So, we did not have the benefit of a reasoned judgment in that case. However in the Nigerian case of J. A. Adediran \& Anr. v. Interland Transport Limited. ${ }^{4}$, the noise made by a set of trailers owned by a company, in the course of taking off in the morning and returning to park in the garage in the evening, was one of the factors which the Supreme Court held as constituting nuisance. Similarly, the gas flaring activities of Nigerian Gas Companies in their various locations constitute not only a nuisance but a source of destruction to many people who inhabit the surrounding villages. And, much as these noise making activities and gas flaring exercises constitute a nuisance, so are they also illegal and could lead to proper actions in the court of law.

\section{Interference from 0ther Activities of Man}

Aside noise, different activities of man being carried out on his own land have caused the disruption of another person's affair on the adjacent land, and these had, often times, led to the institution of multi-million dollars suits which dragged for many years on end. For instance, the case of Rylands v. Fletcher would afford us a good illustration at this juncture. In the case, the Defendants employed independent contractors to build a reservoir on their land. Through the negligence of the independent contractors, disused shafts upon the site, which communicated with the mine of the Plaintiffs beneath the reservoir, were not blocked up. On the filling of the reservoir, the water escaped down the shafts and flooded the mine of the Plaintiffs. Though, the Defendants were not themselves negligent or vicariously liable for the negligence of their independent contractors, they were nonetheless held liable by the Court of Exchequer Chamber and the House of Lords. There is also the case of distress damage feasant which is similar to that of Rylands $v$. Fletcher. It is a situation in which an animal escapes from the land of a man to cause damage and/or interfere with the land of another person. These are other varieties of interference with the use of land by the owner(s) of adjacent property. For instance, water may escape from one man's land and run into the land of another and, apart from making noisy splashes while running through the land of that other man such water may cause monumental damages to the buildings and any other structures or edifices on that land. Other objects such as animals, noxious gas or even chemical may escape and cause similar noise or damage both to the property and person of another. An instance is found in the case of Machine Uudje \& Anr. v. Shell-BP Petroleum Development Company of Nigeria Limited in which the Appellant, while prospecting for crude oil on the area of land adjoining the land of the Respondent, allowed crude oil to escape from an oil-waste pit (constructed by the Appellant Company) and spread over the farm-land of the Respondent, killing a large quantity of fishes. As there was un-contradicted evidence of these facts, the Supreme Court of Nigeria did not mince words in holding the Appellant liable in damages.

${ }^{4} 9$ NWLR (Pt. 214) 155.

${ }^{5} 1975$ (9-10 SC) 155. 
Moreover, it should be noted that the case of Ryland v. Fletcher, though closely similar to Nuisance, can still be distinguished from the latter in many respects. Those differences are easily seen in the degree of liability of the Defendants and the remedies available to the Plaintiffs. For example, should a Defendant accumulate something on his land which later escapes, whether he was negligent in allowing that thing to escape or whether it was foreseeable that the thing would escape, giving the particular circumstance, the Defendant is still liable although he would be excused if it is an act of third party or an act of God that caused the escape. On the other hand, in Nuisance, the Defendant will be held liable for any occurrence on his land which causes damages to the Plaintiff's property where that occurrence on his land is foreseeably likely to cause substantial interference with the Plaintiff's use of his own land. Again, in Ryland v. Fletcher, the occupier of a land is liable where an independent contractor accumulates an object on the land of the occupier and that object later escapes to the land of another. Finally, in this regard, damage by fire may give rise to a claim in Ryland v. Fletcher just as it may do in Nuisance.

\section{Statutory Legal Regime}

All that has been said so far concerns the state of the common law as regards the law of Nuisance in Nigeria. The governments of the different states of Nigeria have not been silent over the discomfort being experienced by the citizens of the country in nuisance cases. Both the Federal and States' governments have enacted different law on the matter but that of the Federal Government is the National Environmental Standards and Regulations Enforcement Agency (Establishment) Act, 2007 which aims at dealing with the nuisance of noise pollution. The Act empowers the Agency to:

1) identify major noise sources, noise criteria and noise control technology; and

2) make regulations on noise, emission control, abatement, as may be necessary to preserve and maintain public health and welfare.

Laudable as the law may look, however, its problem lies with the enforcement of its provision. Little is being done to ensure that the citizen comply with the law, especially, in the obscure parts of the cities.

Furthermore, the National Policy on the Environment, 1988 also provide for certain steps to be taken to ensure that the society is free from unnecessary and unwanted noise. These are to:

1) set up standards including acoustic guarantees;

2) prescribe guidelines for the control of neighbourhood noise especially with respect to construction sites, market and meeting places.

3) prescribe permissible noise level in noise-prone industries and construction sites and to ensure the installation of noise dampers on noise equipment;

4) set up quiet zones especially within game parks, reserves and recreational centres; 
5) ensure compliance with stipulated standards by conducting periodic audit checks.

Similarly, the National Environmental Protection (Pollution Abatement in Industries and Facilities Generating Wastes) Regulation of 1991 directed that all designated industrial layouts be separated from residential areas and create buffer zones separating industrial areas from residential areas. And, finally, the National Guidelines and Standards for Environmental Pollution Control in Nigeria of 1991 were aimed at monitoring and controlling industrial and urban pollution.

Moreover, the enforcement of the policies in the country today leaves a lot to be desired as the various bodies that are expected to carry out the enforcement are neither active nor effective in performing those duties. The effective thing that could promote and guarantee continuous public health and welfare is the constant checks on buildings, structures and other construction works going on in the various sites all over the federation so as to ensure that they comply with the required standard.

\section{Cultural Dimension}

All issues concerning interference with land are naturally connected with the cultural differences and environmental variances among the various ethnic groups and their geographical locations. Thus, the volume of noise that will constitute a nuisance in Ajegunle area of Lagos will certainly not be tolerated in Adeniyi Jones Area of Ikeja in the same Lagos metropolis. This is simply due to the fact that while Ajegunle is located in the slummy part of Lagos, Adeniyi Jones is situated in the Government Reservation Area of the city.

The culture of doing things with impunity and taking things for granted, while assuming that they are properly done, flow more with the people living in the high density areas of the society. They often mount cone speakers on the minaret erected on top of their mosques, and display loud speakers in their churches, with heavy noise emanating from the equipment to disturb the serenity of the community. This sort of thing is not easily observable in the low density and high-brow societies such as Government Reserved Areas or Estates. Again, the people living in the high density communities are usually afraid of such things as witchcraft and sorcery as they easily believe that should they accuse their neighbours of disturbing them with noise emanating from their houses, they might be afflicted with diseases of various kinds or, even, death. It is unlike the European countries where each man lives his life as he desires. They have no fear, no threat and no belief in being killed by an unseen force or person against whom they have supposedly committed an offence. Again, in Africa, it is viewed as an offence to institute action(s) in court against one another as; for instance, the Yoruba (an African ethnic group) believe in the saying that a kii ti kotu bo ki a sore, that is, we do not return from court and remain friends. Once you take your neighbour to court, the door of enmity is eternally opened between the two of you. It is, thus, quite un-African to take your neighbour to court. It is simply 
an anathema, forbidden and unheard of. There is therefore, that natural inclination on the part of Nigerians to avoid any conflict which may lead to instituting legal actions against their neighbours (Odunsi, \& Ogunleye, 2007).

\section{Suggestions}

The quest for peace among individuals, communities, nations and countries of the world cannot be over-emphasised and in order that sustainable peace may prevail all over the place, it is high time that people were enlightened on the uses to which they put their landed property. This is necessary in order to foster a society which is filled with harmony and concord where no one will feel cheated and thereby prevent litigations, conflict and chaos in our various communities.

Moreover, the advancement of science and technology should be harnessed in this part of the world as there abound series of technological equipment such as insulators and sound proof equipment which the government could instruct the citizens to install on the doors, wall and ceilings of their houses and other structures so as to prevent the health hazard which noise pollution may cause to both human and the environment. It has even been suggested that our urban areas could be zoned to maintain a separation between residential area and zones of excessive noise (Alawode, Stephen, \& Adeyemi, 2008). Finally, given the disturbing and unfavourable effect which noise pollution usually has on the environment, human health and wellness, there is need for education, enlightenment and sensitisation of the citizenry on the harmful effects of noise on human health and the environment.

\section{Conclusion}

Apparently, the use which a man makes of his landed property at any particular point in time will determine the ease with which he would live in the area where his structure is located. The use may be laudable and even substantially money-generating, if it is unfit for the purpose of co-existence with other neighbours in the area it may be difficult for his building or structure to stay in the locality. Moreover, the cohabitation of people in the same locality is not only good but highly beneficial in the sense that they would jointly share in the enjoyment of the security, peace and harmony of the environment.

Having gone this far and in order that other researchers may better study this topic in the future, it is suggested that the searchlight of investigation should be directed at the possibility of graduating the level of noise in the different areas in the country so as to designate the low and high density areas with the tag of the level of noise befitting them. Another area deserving closer scrutiny is the ability of the law enforcement agents to enforce the provisions of the relevant Laws on environmental pollution,

\section{Conflicts of Interest}

The authors declare no conflicts of interest regarding the publication of this paper. 


\section{References}

Adesanya, I. O. (2011). Environmental Effects of Church Proliferation: the Redeemed Christian Chiurch of God as a Case Study, International Journal of Humanities and Social Sciences, 1, 177-182.

Alawode, A. J., Stephen, J. T., \& Adeyemi, G. T. (2008). Health, Safety and Environmental Issues in Nigerian Manufacturing and Processing Industries. Journal of Engineering and Applied Sciences, 3, 634-641.

Albert, I. O., Awe, T., Herault, G., \& Omitogun, W. (1995). Informal Channels for Conflict Resolution in Ibadan, Nigeria, Ibadan, IFRA (p. 16). Oyo State, Nigeria: Institute of African Studies, University of Ibadan. https://doi.org/10.4000/books.ifra.705

Asulumien, E. (1984). The Challenge of Noise to Public Health. The Guardian Newspaper, 5 December 1984.

Ayantayo, J. K. (2005). Sociological Examination of Inter-Religious Conflict in Africa. In I. O. Albert (Ed.), Perspective on Conflict and Peace in Africa (p. 57). Ibadan: John Archers Ltd.

Azeez, O., \& Onyema, M. C. (2013). Conflicts of Land Tenure and Tree Tenure on Land Use and Management among Agro-Based Households in Nigeria. International Journal of Advance Agricultural Research, 1, 53-61.

Bruce, J. W. (1988). Rapid Appraisal of Tree and Land Tenure. FAO Community Forestry Note, No. 5.

Clerk, J. F., Lindsell, W. H. B., \& Brazier, M. (1995). Clerk and Lindsell on Torts (p. 560). London: Sweet \& Maxwell Limited.

Dickson, T. U., Audu, S. D., \& Nwaoma, S. M. (2012). The Effect of Religious Noise on the Environment of Ilishan Remo, Ogun State. Babcock Journal of Management and Social Sciences, 10, 3-18.

Field, J. M. (1993). Effects of Personal and Situational Variables upon Noise Annoyance in Residential Areas. Journal of the Acoustical Society of America, 93, 2753-2763. https://doi.org/10.1121/1.405851

Keke, O. V. (2014). An Analysis of the Conceptual Issues Affecting Land Ownership/Importance among the People of Ogbe Autonomous Community in Ahiazu Mbaise of Imo State. British Journal of Environmental Sciences, 2, 1-6.

Kodilinye, G., \& Aluko, O. (2010). Nigerian Law of Torts (p. 95). Ibadan: Spectrum Books Limited.

Njogu, J. G., \& Dietz, T. (2006). Land Use and Tenure Entitlement Rights for Community Based Wildlife and Forest Reservation in Taifa Taveta, Kenya. IDS Working Paper Number 542, Nairobi: Institute for Development Studies, University of Nairobi.

Odunsi, B., \& Ogunleye, T. A. (2007). Noise Pollution and Environment: The Nigerian Perspective. 5th International Conference on International Environmental Law, New Delhi, 8-9 December 2007.

Okorodudu-Fubara, M. T. (1998). Law of Environmental Protection. Materials and Text, Ibadan: Ibadan Celtop Publication Limited.

Otite, \& Ogionwo, W. (2001). An Introduction to Sociological Studies. Ibadan: Heinemann Educational Books (Nigeria) Plc.

Poteete, A. R. (2010). Analysing the Politics of Natural Resources: From Theories of Property Rights to Institutional Analysis and Beyond. In I. E. Vaccaro, E. Smith, \& S. Asazni (Eds.), Environmental Social Sciences: Methods and Research Design (pp. 57-79). New York: Cambridge University Press. 
Read, W. A. et al. (2013). The New International Webster Comprehensive Dictionary of the English Language. Standard International Media Holdings, United States of America.

Street, H. (1976). Street on Torts (6th ed., p. 218). Brisbane: Butterworth \& Co.

Sugden, F. G. (1980). Health Protection in the Urban Environment. London: Associated Business Press.

Uchendu, V. C. (1965). The Igbo of Southeast Nigeria. New York: Holt Rinehart and Winston.

Vijayalakshmi, K. S. (2003). Noise Pollution. In M. J. Bunch, V. Madha Suresh, \& T. Vasantha Kumaran (Eds.), Proceedings of the Third International Conference on Environment and Health (pp. 597-603). Chennai: Department of Geography, University of Madras and Faculty of Environmental Studies, York University.

\section{Statutes}

1) National Environmental Standards and Regulations Enforcement Agency (Establishment) Act, 2007

2) National Policy on the Environment, 1988

3) National Environmental Protection (Pollution Abatement in Industries and Facilities Generating Wastes) Regulation of 1991

4) National Guidelines and Standards for Environmental Pollution Control in Nigeria of 1991 